\title{
Emotional Creativity: A Meta-analysis and Integrative Review
}

\author{
Martin Kuška ${ }^{1,2}$, Radek Trnka ${ }^{1,2}$, Josef Mana $^{1,3}$, Tomas Nikolai1,3 \\ ${ }^{1}$ Prague College of Psychosocial Studies, Czech Republic \\ ${ }^{2}$ OUSHI, Palacky University, Czech Republic \\ ${ }^{3}$ Charles University, Czech Republic
}

\begin{abstract}
Emotional creativity (EC) is a pattern of cognitive abilities and personality traits related to originality and appropriateness in emotional experience. EC has been found to be related to various constructs across different fields of psychology during the past 30 years, but a comprehensive examination of previous research is still lacking. The goal of this review is to explore the reliability of use of the Emotional Creativity Inventory (ECI) across studies, to test gender differences and to compare levels of EC in different countries. Thirty-five empirical studies focused on EC were retrieved and the coefficients required for the meta-analysis extracted. The meta-analysis revealed that women showed significantly higher EC than men (total $N=3,555)$. The same gender differences were also found when testing scores from three ECI subscales, i.e. emotional novelty, emotional preparedness and emotional effectiveness/authenticity. When comparing EC in 10 different countries (total $N=4,375$ ), several cross-cultural differences were revealed. The Chinese sample showed a significantly lower average ECI total score than all the other countries. Based on the integration of results, the avenues for future research on EC and the breadth of influence of the concept of EC across different fields of psychology are discussed.
\end{abstract}

Note: This is the preprint version of the manuscript, the published article is available at https://doi.org/10.1080/10400419.2020.1751541

Keywords: Emotional Creativity, Review, Meta-Analyses, Meta-Analysis, Definition, Emotional Creativity Inventory, ECI, Reliability, Gender Differences, Cross-cultural, Cross-culture, Personality Traits, NEO Personality Inventory, Big Five, Extraversion, Agreeableness, Openness to Experience, Introversion, Neuroticism, Emotions, Creativity, Cognition, Cognitive Abilities, Affect, Fantasy, Coping, Alexithymia, Anhedonia, Self-understanding, Motivation, Creativeness, Innovative Performance, Creative Ability, Artistic Creativity, Creative Thinking

MeSH Headings: Emotions, Creativity, Affect, Affective Symptoms, Gender, Sex, Gender Identity, Cross-Cultural Comparison, Transcultural Studies, Temperament, Extraversion, Neuroticism, Anhedonia, Creativeness, Cognition, Cognitive Function, Artistic Creativity, Creative Ability, Creative Thinking 
Emotional creativity (EC) is a pattern of cognitive abilities and personality traits related to originality and appropriateness in emotional experience (Averill, 1999; Ivcevic, Brackett, \& Mayer, 2007). It significantly pervades human creative performance, because it involves one's ability to connect with the reasons for and consequences of emotional responses at the preparation stage of the creative process as well as to experience and express novel emotions at the verification stage of the creative process (Averill, 1999; Soroa, Gorostiaga, Aritzeta, \& Balluerka, 2015). Therefore, it is not surprising that higher $\mathrm{EC}$ has been found to be related to the increased involvement of participants in creative leisure-time activities, e.g. creative writing, painting, composing music, dance improvisation, theatrical improvisation and do-ityourself activities (Trnka, Zahradnik, \& Kuška, 2016).

EC is considered to be one of three main areas of general creativity, together with nonverbal and verbal creativity and creativity in problem solving (Ma, 2009). The important feature of EC is a divergence from the ordinary emotional experience, because it involves the cognitive abilities that enable cognition to diverge from common and generate novel emotional reactions (Ivcevic et al., 2007; Trnka, Cabelkova, Kuška, \& Nikolai, 2019). Emotionally creative abilities have been found to be closely related to cognitive abilities supporting innovative performance, i.e. idea generation, promotion and realization (Wang, Huang, \& Zheng, 2015).

The Emotional Creativity Inventory (ECI, Averill, 1999) is the most widely used instrument for measuring EC. The ECI consists of three subscales: (1) Preparedness, comprising understanding and learning from one's own and others' emotions, (2) Novelty, referring to the ability to experience unusual emotions, and (3) Effectiveness/Authenticity, linked to the skill to express emotions adroitly and honestly 
(Averill, 1999). During the past two decades, the ECI has been found to correlate with a wide spectrum of other scales and measures (for an overview, see Electronic Supplementary Material 1). For example, the ECI positively correlated with openness to experience (Averill, 1999, Study 3; Ivcevic et al., 2007; Luke \& Zychowicz, 2014) and agreeableness subscales of the NEO Personality Inventory (Averill, 1999, Study 3) or with hope and positive affect (Sharma \& Mathur, 2016). Among others, the ECI negatively correlated with alexithymia (Fuchs, Kumar, \& Porter, 2007) and apathy accompanying cognitive deficits in late adulthood (Trnka et al., 2019).

Despite the applied significance of EC and the number of empirical studies reporting various relationships with other variables, to our knowledge, no review summarizing the evidence concerning EC has been published so far. The present review aims to summarize the existing empirical evidence that includes EC and to integrate recent knowledge on EC into a comprehensive framework.

\section{METHOD}

\section{Eligibility criteria}

The current review retrieved all empirical studies concerning EC published in peerreviewed resources written in the English (30 papers), or Russian (5 papers) languages. The main criterion for including the paper into the review was that EC was investigated empirically in the given study (other inclusion criteria: the language of the publication is English, German or Russian; the full text is available; the paper is published in a peer reviewed source; exclusion criterion: the methodological quality of the paper is recognized as poor). The review was elaborated in accordance with the Preferred Reporting Items for Systematic Reviews and Meta-Analyses (PRISMA) guidelines (Moher, Liberati, Tetzlaff, \& Altman, 2009) and recommendations of the Cochrane Collaboration (Higgins \& Green, 2008). 
[please, insert Figure 1 about here]

\section{Search strategy and extraction of findings}

All the appearances of EC in peer-reviewed papers accessible via Google Scholar, EBSCO and the Web of Science were considered. The exact phrase was emotional creativity for Google Scholar and emotional WO creativity for EBSCO, respectively. The subsequent phrases were emotion* creativ* and emotion* WO creativ*, respectively.

As of 24 April 2018, database searches generated 1290 occurrences of EC (see Figure 1). Doctoral dissertations, MA theses and popular papers were excluded. After removing duplicates, the full-texts of 198 papers were screened for relevance. All full texts of the selected papers were then examined to exclude papers in which EC was only mentioned, without any empirical findings involving EC.

Finally, 35 empirical journal papers dealing with EC were selected (see Electronic Supplementary Material 1). Subsequently, the reference lists of the retrieved manuscripts were scanned for relevant sources, and these sources were later retrieved. Forward tracking was conducted with the Times cited tool provided by the Web of Science. This operation did not reveal any other papers relevant for inclusion into the review.

All empirical findings involving EC were independently extracted by two reviewers (TN and MK). The following information was collected: (1) a description of the results of empirical findings regarding EC, (2) the methodological quality assessed using the PRISMA-P protocols (Shamseer et al., 2015). For the purposes of meta-analysis, all the EC-relevant data were excerpted from the papers. When insufficient data were available from the papers, the authors were contacted to request missing data. 


\section{RESULTS}

\section{Disciplinary reach of the EC concept and distribution of citations in time}

The disciplinary reach of Averill's (1999) fundamental paper introducing EC and the method of its measurement, the ECI, was assessed. To reveal the disciplinary reach, the method of Starr and Zurbriggen (2017) for mapping citations in time was applied. First, all citations of Averill's (1999) paper were tracked on Google Scholar, using the function Cited by for searching in papers containing the given reference. On the 17 January 2019, the search resulted in 224 references. Subsequently, books, theses, dissertations and conference proceedings were excluded from this sample. Onehundred-eight scientific papers containing a citation of Averill's (1999) paper were found in 86 unique journals. Second, these journals were coded for the discipline of the publication outlet.

[please, insert Figure 2 about here]

The largest number of citations (see Electronic Supplementary Material 2) were published in the creativity/cognitive psychology journal category (10) and the same number of citations (10) were found for the category multidisciplinary psychology. Other journals with a higher number of quotations of Averill's (1999) paper were from the social psychology category (8), the personality psychology category (8) and the organizational psychology category, respectively (7). Furthermore, in order to display how the impact of Averill's (1999) concept of EC is distributed in time, a histogram by year was created (Figure 2).

\section{Reliability generalization}

To test the internal consistency of ECI and its subscales, a reliability generalization meta-analysis was conducted (Vacha-Haase, 1998). The summary statistics and its $95 \%$ confidence intervals (CIs) were estimated using an inverse-variance weighted random- 
effects model. To assess possible sources of heterogeneity, meta-regression with language as a moderator was conducted. For all analyses .05 level of statistical significance was used. All analyses were performed using the metafor package (Viechtbauer, 2010) in the software environment for statistical computing $\mathrm{R}$ version 3.4.4 (R Core Team, 2018).

The sample used for the reliability generalization analysis of the ECI global scale $(N=5,479)$ consisted of fourteen studies that used the whole 30-item ECI questionnaire, two studies that used a shortened 17-item version (Soroa et al., 2015; Oriol, Amutio, Mendoza, Da Costa, \& Miranda, 2016) and one study that used an abridged 13-item version (Gutbezahl \& Averill, 1996). The sample used for the reliability generalization analysis of the three ECI subscales (Novelty, Preparedness and Effectiveness/Authenticity) $(N=6,284)$ consisted of fifteen studies that used the full version of the ECI, two studies that used a shortened 17-item version (Soroa et al., 2015; Oriol et al., 2016) and one study that used a shortened 28-item version (Soroa et al., 2016).

Table 1 presents descriptive statistics of the sample, estimated summary statistics with its $95 \%$ CIs and statistics assessing heterogeneity. The meta-analysis revealed acceptable alpha values for the ECI global scale (alpha $=.84,95 \%$ CI $[.81, .86])$ and the subscales (alphas $\geq .75$ ).

\section{[please, insert Table 1-2 about here]}

Seven different languages (English, French, Spanish, Georgian, Persian, Russian and Czech) were considered as moderators for the ECI global scale and six different languages (English, Spanish, Georgian, Persian, Russian and Czech) were considered as moderators for all three ECI subscales. Table 2 presents the results of the test of moderators, heterogeneity measures of the moderator models and the amount of 
heterogeneity accounted for by the models. The language did not moderate the ECI total score. In contrast, the language moderated the Novelty, Preparedness and Effectiveness/Authenticity subscales' scores. The language in which the ECI was administered predicted $2 \%$ of the reliability heterogeneity across studies when the overall scale effect size was the criterion, $73 \%$ of the reliability heterogeneity across studies when the Novelty subscale effect size was the criterion, $63 \%$ of the reliability heterogeneity across studies when the Preparedness subscale effect size was the criterion and $40 \%$ of the reliability heterogeneity across studies when the Effectiveness/Authenticity subscale effect size was the criterion.

\section{Gender differences in EC}

To find out if there is a gender difference in EC and its components, a randomeffects model meta-analysis with gender as the independent and ECI and its subscales scores as the dependent variables was conducted. The sample used for the analysis of gender differences $(N=3,555)$ consisted of seven studies that used the whole 30 -item ECI questionnaire and one study that used a shortened 17-item version (Soroa et al., 2015).

\section{[please, insert Table 3 and Figure 3 about here]}

The analysis identified significantly higher total scale ECI scores, higher Novelty subscale scores, higher Preparedness subscale scores, and higher Effectiveness/Authenticity subscale scores in women than in men (see Table 3 and Figure 3). Several studies fell behind the borders of the funnel plot (see Electronic Supplementary Material 3), however, Kendall's tau rank correlation tests and Egger's regression tests for funnel plot asymmetry did not indicate a risk of publication bias. 


\section{EC across nations}

To characterize how the nationality affects EC and its components, a metaregression with nationality of the sample as the independent and the ECI and its subscales scores as the dependent variables was conducted. Because the raw means of ECI scores are a function of the number of items in the scale, only studies using the full ECI questionnaire and/or full ECI subscales were included in the respective analyses. The sample used for the analysis consisted of 28 samples $(N=4,375)$ for total ECI score, 20 samples $(N=2,609)$ for Novelty and Preparedness, and 19 samples $(N=$ 2,529) for Effectiveness/Authenticity.

The ECI total scores of ten different nations (China, Czech Republic, France, Georgia, India, Iran, Korea, Russia, the UK and the USA) were compared. After applying the Bonferonni correction for multiple comparisons, there were significantly lower total ECI scores in the Chinese sample than in samples from all the other countries $(Z=4.47-9.68$, ps $<.001)$ as well as in the Korean sample than in the samples from India $(Z=3.96, p<.001)$, Iran $(Z=3.47, p<.001)$ and Russia $(Z=4.06, p<$ .001). There were marginally significant lower total ECI scores in the Korean sample than in samples from Georgia $(Z=3.19, p=.001)$ and the USA $(Z=3.28, p=.001)$ and in the French sample than in samples from India $(Z=2.47, p=.013)$ and Russia $(Z$ $=2.46, p=.014)$.

The ECI Novelty, Preparedness and Effectiveness/Authenticity scores of seven different nations (China, Czech Republic, Georgia, Iran, Korea, Russia and the USA) were compared. After applying the Bonferonni correction for multiple comparisons, there were significantly lower Novelty scores in the Chinese sample than in the samples from all the other countries, except Korea $(Z=3.14-6.63$, ps $<.002)$, as well as than in the Korean sample in the samples from Georgia $(Z=4.46, p<.001)$, Iran $(Z=4.32, p$ 
$<.001)$, Russia $(Z=5.04, p<.001)$ and the USA $(Z=4.13, p<.001)$. There was a marginally significant lower Novelty score in the Korean sample than in the Czech sample $(Z=2.20, p=.028)$. After applying the Bonferonni correction for multiple comparisons, there were significantly lower Preparedness scores in the Chinese sample than in the samples from $\operatorname{Iran}(Z=3.17, p=.002)$, Russia $(Z=3.06, p=.002)$ and the USA $(Z=3.27, p=.001)$. There were marginally significant lower Preparedness scores in the Chinese sample than in samples from the Czech Republic $(Z=2.68, p=.007)$, Georgia $(Z=2.12, p=.034)$ and Korea $(Z=2.44, p=.015)$. After applying the Bonferonni correction for multiple comparisons, there were significantly lower Effectiveness/Authenticity scores in the Chinese sample than in the samples from all the other countries $(Z=3.57-5.66, p<.001)$.

[please, insert Figure 4 about here]

\section{Frequency of word-occurrence of EC-related terms}

A quantitative content analysis was employed to reveal which words occur together in relatively close proximity to terms expressing EC in empirical papers included in the meta-analysis (Electronic Supplementary Material 1). Non-English written papers were excluded. Figure 4 shows that EC mostly co-occurred with the word emotion (481x). Others of the most frequently co-occurred words were relation $(417 \mathrm{x})$ and correlation (409x).

\section{DISCUSSION}

The present review on EC integrated findings across a wide spectrum of psychological research and showed the reach of Averill's concept of EC (1999). The analysis of journal papers referencing Averill's concept (1999) provided insights into the reach and breadth of influence of this concept. Overall, the analysis showed that the concept of EC has succeeded in reaching a relatively large audience, both 
internationally and across disciplines. When considering the reach within different subdisciplines of psychology, EC was cited mostly in cognitive psychology and creativity research, personality psychology, social psychology, organizational psychology, theoretical psychology and multidisciplinary or non-specific psychological journals. Furthermore, the distribution of citations in non-psychology journals showed the reach outside of psychology. These journals ranged from life science/environmental journals to medical, pharmacological and health service/nursing journals.

Furthermore, significant gender differences were found in EC and its subscales. The meta-analysis identified higher ECI total scores in women than in men. Furthermore, women scored higher in all three subscales - Novelty, Preparedness, and Effectiveness/Authenticity - across studies. The results make apparent that women are more emotionally creative than men. From the perspective of emotional novelty, women more often perceive their own emotions as original, unique, uncommon and improbable when compared to men. Women also think more about their own emotional reactions and emotional experiences and search for the reasons for their own feelings. They also pay more attention to other people's emotions in an effort to better understand their own feelings than men. The higher scores of women in the authenticity/effectiveness dimension, when compared to men, indicated a more effective response in situations requiring new or unusual emotional responses and the tendency to believe that emotions may help in achieving one's own life goals. These findings are also in accordance with the results of a recent meta-analysis of da Costa, Páez, Sánchez, Garaigordobil, and Gondim (2015), which revealed slightly higher cognitive creativity in women than in men.

The results of the current meta-analysis revealed excellent reliability for the ECI total score. However, the reliabilities for particular subscales were lower than for the 
ECI total score, though they were still acceptable. The ECI has been proved to be a suitable research instrument for measuring EC in different cultures. The moderator analysis showed that the reliability of the ECI total score was not influenced by language adaptation of the ECI. In other words, different language adaptations of the ECI did not lead to different reliability, i.e. the psychometric properties were not altered when different language versions were used. However, the language moderated all three ECI subscales. This finding should lead to caution when interpreting the results from the ECI subscales in cross-culturally designed studies. The reliability of the Novelty subscale was identified as the most prone to be influenced by the different language adaptations of the ECI. Also, the reliability of the Preparedness subscale was found to be vulnerable to being influenced by the language adaptation. In contrast, the Effectiveness/Authenticity subscale was minimally affected by the language adaptation.

The analysis of cultural differences identified lower ECI total scores in the sample from China, in comparison to all the other countries. Furthermore, the sample from Korea showed lower ECI total scores than the Indian, Iranian, Russian, Georgian and American samples. One may ask which factors contributed to these cross-cultural differences. A possible explanation may be related to differences in emotion-related values. Emotions generally have a very low value in China (Eid \& Diener, 2001). As Eid and Diener (2001) pointed out, a Chinese sample consistently showed the lowest experiences in almost all emotions, because Chinese culture considers emotions as dangerous, irrelevant or even illness-causing. Regulation strategies, such as the suppression of emotions, are generally suggested to be highly valued in East Asian cultures, and the value of a moderated emotional life can also be found in these cultures (Trnka, Šolcová, \& Tavel, 2018). Future research on cross-cultural differences in 
emotion-related values should provide us with further insights into various levels of EC in different countries and cultures.

The content analysis revealed the co-occurrence of words that emerged in close relation to EC in previous empirical studies focused on EC. EC was found to occur frequently with the words relation, correlation, or significant (Figure 4). This indicates that empirical research following the introduction of Averill's concept of EC (1999) was mostly correlational, exploring various relations of EC with other constructs or variables. In a more detailed look at the correlations that have been found to be significant in previous research, the correlations of the ECI total score (Figure 5) and correlations of the ECI subscales with other variables (Figure 6) can be distinguished. Figure 5 integrates all the known direct correlations of the ECI total score, distinguishing positive and negative correlations. The ECI total score correlated (1) positively to personality traits, such as extraversion (namely with facets of warmth and positive emotions), openness to experience (all its facets) and neuroticism; (2) positively to creative dispositions (e.g., fantasy proneness); (3) positively to the escapeavoidance coping strategy; and (4) negatively to alexithymia.

[please, insert Figure 5-7 about here]

Furthermore, the network of relationships showing various correlations of the ECI subscales, i.e., Preparedness, Effectiveness/Authenticity and Novelty, with other variables has been revealed (Figure 6). This network integrates statistically significant correlations, both the positive and the negative, and enables us to see the embedding of EC across different, mostly personality-trait constructs. The ECI's Preparedness subscale correlated positively with social anhedonia, introversion and agreeableness. Furthermore, agreeableness also positively correlated with the Effectiveness/Authenticity subscale of the ECI. This subscale was also negatively 
correlated to conscientiousness and the escape-avoidance coping strategy and positively correlated to neuroticism, as measured by the NEO-PI. The Novelty subscale of the ECI correlated positively to measures of the ability to make connections between distant areas and also to the escape-avoidance coping strategy.

Furthermore, content analysis showed that the EC occurred frequently with the word ability (Figure 4). Indeed, many of empirical studies reviewed in the present study (Electronic Supplementary Material 1) revealed that EC was a positive moderator for various abilities, skills and dispositions (Figure 7). Teaching efficacy, selfunderstanding, awareness of professional roles, innovative performance and intrinsic motivation of employees are examples of skills and abilities that have been found to be positively moderated by EC. These results may have practical implications for applied settings, where the above-mentioned skills are desirable.

\section{REFERENCES}

Abuladze, N., \& Martskvishvili, K. (2016). No words for emotions: Emotional creativity and alexithymia in art. Problems of Psychology of 21 st Century, 10, 62-68.

Andreeva, I. (2011). Adaptation of Emotional Creativity Inventory (ECI). Psihologicheskij Zhurnal, 1-2, 75-81.

Averill, J. R. (1999). Individual differences in emotional creativity: Structure and correlates. Journal of Personality, 67, 331-371. doi: 10.1111/1467-6494.00058

da Costa, S., Páez, D., Sánchez, F., Garaigordobil, M., \& Gondim, S. (2015). Personal factors of creativity: A second order meta-analysis. Revista de Psicología del Trabajo y de las Organizaciones, 31(3), 165-173. doi: 10.1016/j.rpto.2015.06.002

Derevyanko, S. P. (2017). The role of emotional creativity in the choice of coping strategies. [Engl. transl.]. Vesnik Polackaga Dzyrzhaunaga Universiteta. Seriyja E. Pedagagichnyja Navuki, 7, 87-91.

Dyson, S. B., Chang, Y. L., Chen, H. C., Hsiung, H. Y., Tseng, C. C., \& Chang, J. H. (2016). The effect of tabletop role-playing games on the creative potential and emotional creativity of Taiwanese college students. Thinking Skills and Creativity, 19, 88-96. doi: 10.1016/j.tsc.2015.10.004

Eid, M., \& Diener, E. (2001). Norms for experiencing emotions in different cultures: Inter- and intranational differences. Journal of Personality and Social Psychology, 81(5), 869-885. doi: 10.1007/978-90-481-2352-0_9 
Frolova, S. V. (2016). Training of emotional creativity and development of adaptive personal qualities. International Annual Edition of Applied Psychology: Theory, Research, and Practice, 3, 78-85.

Frolova, F. V., \& Novoselova, K. I. (2015). Emotional creativity as a factor of individual, family and psychological well-being. International Annual Edition of Applied Psychology: Theory, Research, and Practice, 2, 31-43.

Fuchs, G. L., Kumar, V. K., \& Porter, J. (2007). Emotional creativity, alexithymia, and styles of creativity. Creativity Research Journal, 19, 233-245. doi: 10.1080/10400410701397313

Ghadiri nezhdyan, F., \& Abdi, B. (2010). Factor structure of Emotional Creativity Inventory (ECI-Averill, 1999) among Iranian undergraduate students in Tehran universities. Procedia: Social and Behavioral Sciences, 5, 1836-1840. doi: 10.1016/j.sbspro.2010.07.374

Golubina, J. J. (2013). The interrelation between emotional creativity and emotional intelligence. [Engl. trans.]. Pedagogy and Psychology of Education, 1, 80-86.

Gutbezahl, J., \& Averill, J. (1996). Individual differences in emotional creativity as manifested in words and pictures. Creativity Research Journal, 9, 327-337. doi: 10.1207/s15326934crj0904_4

Higgins, J. P. T., \& Green, S. (2008). Cochrane handbook for systematic reviews of interventions. Chichester, England: Wiley.

Holt, N. J., Simmonds-Moore, C., \& Moore, S. (2008). Benign schizotypy: Investigating differences between clusters of schizotype on paranormal belief, creativity, intelligence and mental health. In Proceedings of presented papers: The parapsychological association 51st annual convention (pp. 82-96). Winchester, England: Parapsychological Association.

Humphreys, J., Jiao, N., \& Sadler, T. (2008). Emotional disposition and leadership preferences of American and Chinese MBA students. International Journal of Leadership Studies, 3, 162-180.

Ivcevic, Z., Brackett, M. A., \& Mayer, J. D. (2007). Emotional intelligence and emotional creativity. Journal of Personality, 75, 199-236. doi: 10.1111/j.14676494.2007.00437.x

Jenaabadi, H., Marziyeh, A., \& Dadkan, A. M. (2015). Comparing Emotional creativity and social adjustment of gifted and normal students. Advances in Applied Sociology, 5, 111-118. doi: 10.4236/aasoci.2015.53010

Lattifian, M., \& Delavarpour, M. A. (2012). An investigation into the relationship between attachment style and mental health by the mediating role of emotional creativity. Advances in Cognitive Science, 2(14), 45-62.

Luke, D., \& Zychowicz, K. (2014). Comparison of outcomes with nonintentional and intentional precognition tasks. The Journal of Parapsychology, 78, 223-234.

Ma, H. H. (2009). The effect size of variables associated with creativity: A metaanalysis. Creativity Research Journal, 21, 30-42. doi: 10.1080/10400410802633400

Martin, E. A., Cicero, D. C., Bailey, D. H., Karcher, N. R., \& Kerns, J. G. (2016). Social anhedonia is not just extreme introversion: Empirical evidence of distinct constructs. Journal of Personality Disorders, 30, 451-468. doi: 10.1521/pedi_2015_29_203 
Martskvishvili, K., Abuladze, N., Sordia, N., \& Neubauer, A. (2017). Emotional creativity inventory: Factor structure, reliability, and validity in a Georgian speaking population. Problems of Psychology in the 21st Century, 11, 31-41.

Moher, D., Liberati, A., Tetzlaff, J., \& Altman, D. G. (2009). Preferred reporting items for systematic reviews and meta-analyses: The PRISMA statement. British Medical Journal, 339, 1-8. doi: 10.1371/journal.pmed.1000097

Moltafet, G., Sadati Firoozabadi, S. S., \& Pour-Raisi, A. (2018). Parenting style, basic psychological needs, and emotional creativity: A path analysis. Creativity Research Journal, 30, 187-194. doi: 10.1080/10400419.2018.1446748

Navaei, M., Hosseinaiy, A., \& Asadi, A. (2014). Relation between personality traits, emotional creativity, and life expectancy in divorced women and normal women of Golestan province. International Journal of Basic Sciences \& Applied Research, 3, 29-33.

Oriol, X., Amutio, A., Mendoza, M., Da Costa, S., \& Miranda, R. (2016). Emotional creativity as predictor of intrinsic motivation and academic engagement in university students: The mediating role of positive emotions. Frontiers in Psychology, 7, 1243. doi: 10.3389/fpsyg.2016.01243

$\mathrm{R}$ Core Team (2018). R: A language and environment for statistical computing. $\mathrm{R}$ Foundation for Statistical Computing, Vienna, Austria. Retrieved from www.rproject.org

Roe, C. A., Martin, H., \& Drennan, S. (2014). Effects of participant and target system lability upon PK performance using an I Ching task. Journal of the Society for Psychical Research, 74, 219-238.

Shamseer, L., Moher, D., Clarke, M., Ghersi, D., Liberati, A., Petticrew, M., ... Stewart, L. A. (2015). Preferred reporting items for systematic review and metaanalysis protocols (PRISMA-P) 2015: Elaboration and explanation. Bmj, 349, 1-25. doi: $10.1136 / \mathrm{bmj} . \mathrm{g} 7647$

Sharma, D. \& Mathur, R. (2016). Linking hope and emotional creativity: Mediating role of positive affect. The International Journal of Indian Psychology, 58, 50-61.

Song, C. (2016). Supervisors' paternalistic leadership influences college English teachers' teaching efficacy in China. Social Behavior and Personality, 44, 13151328. doi: 10.2224/sbp.2016.44.8.1315

Soroa, G., Aritzeta, A., Balluerka, N., \& Gorostiaga, A. (2016). Adaptation and validation of the Basque version of the Emotional Creativity Inventory in higher education. The Spanish Journal of Psychology, 19, 1-13. doi: 10.1017/sjp.2016.26

Soroa, G., Gorostiaga, A., Aritzeta, A., \& Balluerka, N. (2015). A shortened Spanish version of the Emotional Creativity Inventory (the ECI-S). Creativity Research Journal, 27, 232-239. doi: 10.1080/10400419.2015.1030313

Starr, C. R., \& Zurbriggen, E. L. (2017). Sandra Bem's gender schema theory after 34 years: A review of its reach and impact. Sex Roles, 76(9-10), 566-578. doi: 10.1007/s11199-016-0591-4

Sundararajan, L., \& Fatemi, S. M. (2016). Creativity and symmetry restoration: Toward a cognitive account of mindfulness. Journal of Theoretical and Philosophical Psychology, 36, 131-141. doi: 10.1037/teo0000027 
Trnka, R., Cabelkova, I., Kuška, M., \& Nikolai, T. (2019). Cognitive decline influences emotional creativity in the elderly. Creativity Research Journal, 31, 93-101. doi: 10.1080/10400419.2019.1577205

Trnka, R., Šolcová, I. P., \& Tavel, P. (2018). Components of cultural complexity relating to emotions: A conceptual framework. New Ideas in Psychology, 51, 27-33. doi: 10.1016/j.newideapsych.2018.05.001

Trnka, R., Zahradnik, M., \& Kuška, M. (2016). Emotional creativity and real-life involvement in different types of creative leisure activities. Creativity Research Journal, 28, 348-356. doi: 10.1080/10400419.2016.1195653

Vacha-Haase, T. (1998). Reliability generalization: Exploring variance in measurement error affecting score reliability across studies. Educational and Psychological Measurement, 58, 6-20. doi: 10.1177/0013164498058001002

Valueva, E. A. (2009). Diagnostics of emotional creativity: adaptation of the questionnaire of J. Averill. [Engl. transl.]. In D. V. Lusin, \& D. V. Ushakov (Eds.), Social and economic intelligence: From processes to measurement. [Engl. transl.]. (pp. 216-227). Moscow, Russia: Institute of Psychology of the Russian Academy of Sciences.

Valueva, E. A., \& Ushakov, D. V. (2010). Empirical verification of the model of the correlation of subject and emotional abilities. [Engl. transl.]. Psychology: Journal of the Higher School of Economics, 7, 103-114.

Viechtbauer, W. (2010). Conducting meta-analyses in R with the metafor package. Journal of Statistical Software, 36(3), 1-48.

Wang, G., Huang, H., \& Zheng, Q. (2015). Effect of Chinese employees' emotional creativity on their innovative performance. Social Behavior and Personality, 43, 1147-1160. doi: 10.2224/sbp.2015.43.7.1147

Zarenezhad, M., Reisy, J., Shojaei, M., Sasani, S., \& Monfared, P. N. (2013). Predicting academic adjustment based on perfectionism and emotional creativity in high school students. Journal of Life Science and Biomedicine, 3, 393-403.

Zenasni, F., \& Lubart, T. I. (2008). Emotion-related traits moderate the impact of emotional state on creative performances. Journal of Individual Differences, 29, 157167. doi: 10.1027/1614-0001.29.3.157 


\section{TABLES}

Table 1. Reliability of Emotional Creativity Inventory (ECI)

\begin{tabular}{|l|l|l|l|l|l|l|l|l|}
\hline Scale & $\mathrm{k}$ & $\mathrm{N}$ & $\alpha$ & $95 \% \mathrm{CI}$ & Min. & Max. & $\mathrm{Q}$ & $\mathrm{I} 2$ \\
\hline Global Score & 17 & 5,479 & .84 & {$[.81, .86]$} & .69 & .90 & $213.34 * * *$ & $92.8 \%$ \\
\hline Novelty & 18 & 6,384 & .81 & {$[.79, .83]$} & .74 & .90 & $123.30 * * *$ & $86.5 \%$ \\
\hline Preparedness & 18 & 6,384 & .75 & {$[.70, .78]$} & .53 & .82 & $284,08 * * *$ & $93.2 \%$ \\
\hline E/A & 18 & 6,384 & .78 & {$[.74, .81]$} & .57 & .88 & $267.77 * * *$ & $94.1 \%$ \\
\hline
\end{tabular}

Notes: $\mathrm{E} / \mathrm{A}=$ Effectiveness/Authenticity subscale; $\mathrm{k}=$ number of studies; $\mathrm{N}=$ pooled sample size, $\alpha=$ summary estimate of Cronbach's alpha coefficient; CI = confidence interval; Min. = minimal alpha in the sample; Max. = maximal alpha in the sample; $\mathrm{Q}$ $=$ Cochrane's $\mathrm{Q}$ statistic; $\mathrm{I} 2=$ total heterogeneity/total variability; $* * * \mathrm{p}<.001$. 
Table 2. Moderator analyses in reliability generalization

\begin{tabular}{|l|l|l|l|l|}
\hline Scale & $Q_{\text {mod }}$ & $\mathrm{R}^{2}$ & $Q_{\text {error }}$ & $I^{2}$ \\
\hline Global Score & 6.74 & 0.02 & $151.99^{* * *}$ & $91.1 \%$ \\
\hline Novelty & $32.07 * * *$ & 0.73 & $35.96^{* * *}$ & $60.4 \%$ \\
\hline Preparedness & $28.06^{* * *}$ & 0.63 & $72.16^{* * *}$ & $81.7 \%$ \\
\hline E/A & $15.10^{* * *}$ & 0.40 & $124.36^{* * *}$ & $89.4 \%$ \\
\hline
\end{tabular}

Notes: E/A = Effectiveness/Authenticity subscale; $Q_{\bmod }=$ test of moderators statistic; $\mathrm{R}^{2}=$ amount of heterogeneity accounted for by the model; $Q_{\text {error }}=$ test for residual heterogeneity statistic; $I^{2}=$ total heterogeneity/total variability; $* * * p<.001$. 
Table 3. Gender differences in emotional creativity (EC)

\begin{tabular}{|l|l|l|l|l|l|l|l|}
\hline Scale & $\mathrm{k}$ & $N$ & $\begin{array}{l}\text { Effect } \\
\text { size }\end{array}$ & SE & $95 \%$ CI & $Q$ & $I^{2}$ \\
\hline Global Score & 9 & 3,555 & $-.355^{* * *}$ & .055 & {$[-.471,-239]$} & $18.500 *$ & $55.9 \%$ \\
\hline Novelty & 10 & 3,910 & $-.218 * * *$ & .058 & $\begin{array}{l}{[-.332,-} \\
.105]\end{array}$ & $22.323 * *$ & $59.5 \%$ \\
\hline Preparedness & 10 & 3,910 & $-.313 * * *$ & .038 & $\begin{array}{l}{[-.388,-} \\
.239]\end{array}$ & 11.048 & $15.5 \%$ \\
\hline E/A & 10 & 3,910 & $-.306 * * *$ & .050 & $\begin{array}{l}{[-.403,-} \\
.209]\end{array}$ & $17.070 *$ & $45.1 \%$ \\
\hline
\end{tabular}

Notes: $\mathrm{E} / \mathrm{A}=$ Effectiveness/Authenticity subscale; $\mathrm{k}=$ number of studies; $N=$ pooled sample size, Effect size = average random effect size; SE = standard error of mean; CI $=$ confidence interval; $\mathrm{Q}=$ Cochrane's $\mathrm{Q}$ statistic; $I^{2}=$ total heterogeneity/total variability; $* p<.05 ; * * p<.01 ; * * * p<.001$. 


\section{FIGURES}

Figure 1. PRISMA flow chart of study selection

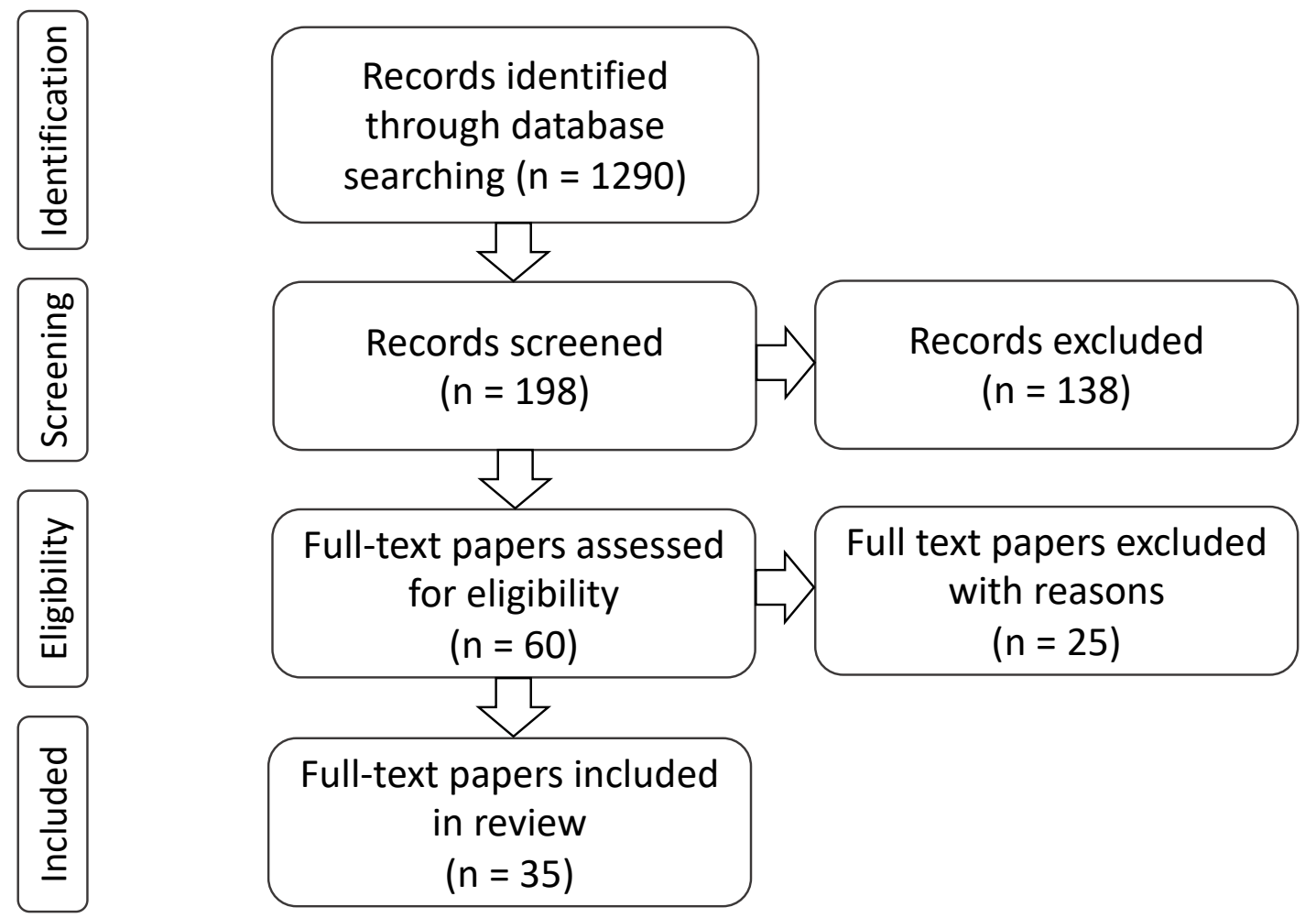


Figure 2. Years of publication of articles citing Averill (1999)

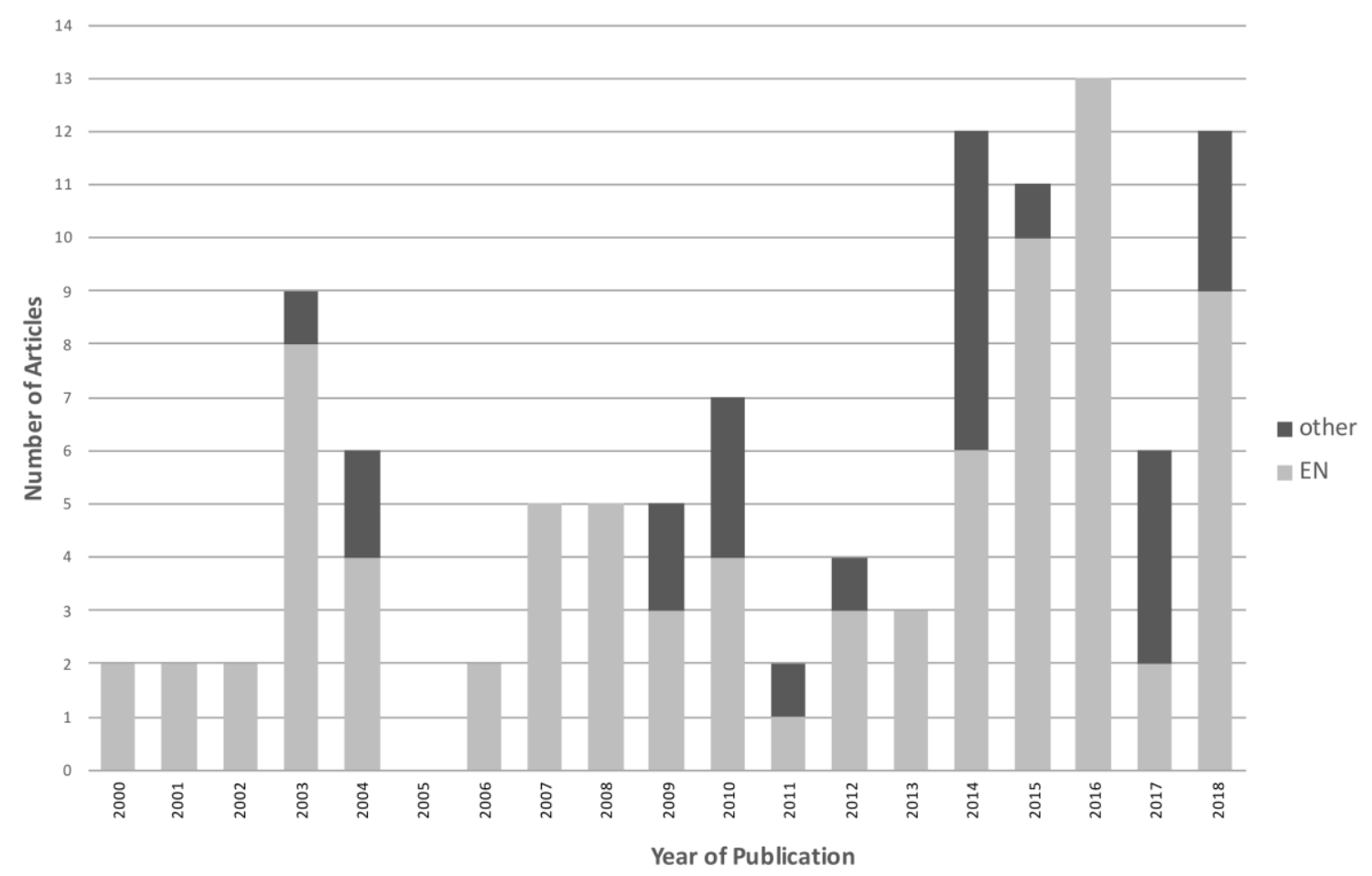

Notes: $\mathrm{EN}=$ English, other $=$ other languages. 
Figure 3. Forest plots for analyses of gender differences in ECI. Negative values mean higher scores in women than in men.

A.Global score

First author (year)

Hedge's g $[95 \% \mathrm{Cl}]$

Averill ( 1999 )
Jenaabadi ( 2015 ).1
Jenaabadi ( 2015 ).2
Latifian ( 2012 )
Martsksvishvili ( 2017 )
Soroa ( 2015 )
Trnka ( 2016 )
Valueva ( 2009 )
Valueva ( 2010 )

Random-effects model

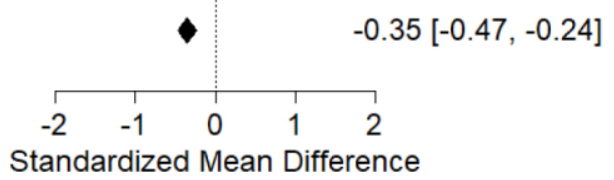

C.Preparedness

First author (year)

Hedge's g $[95 \% \mathrm{Cl}]$

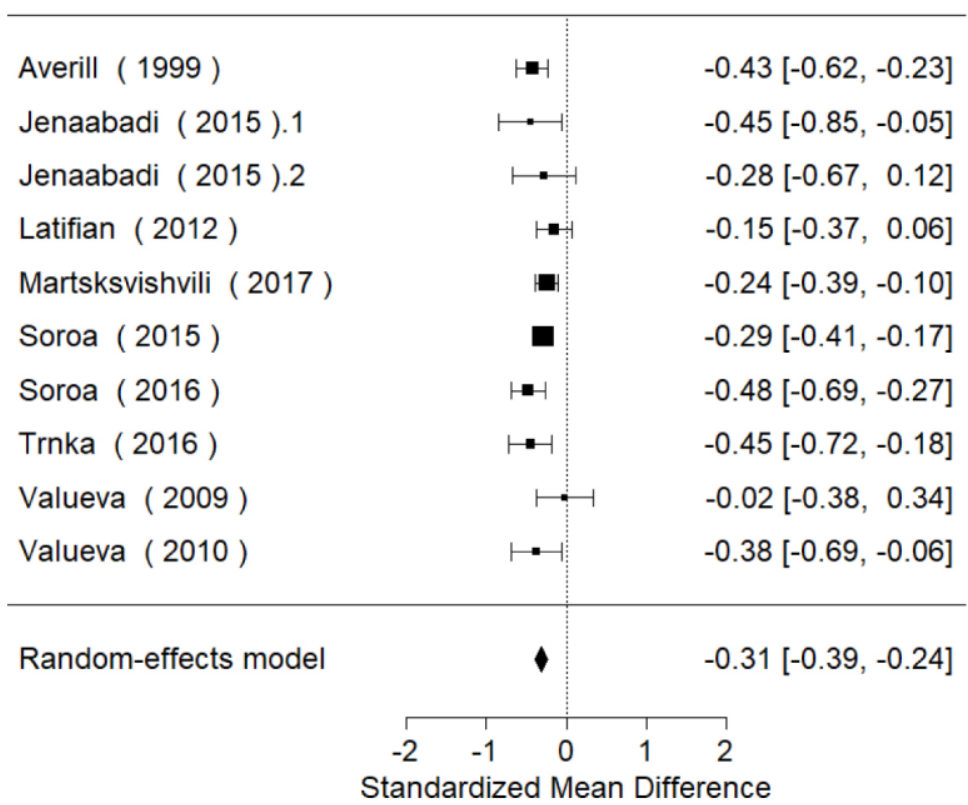

B.Novelty

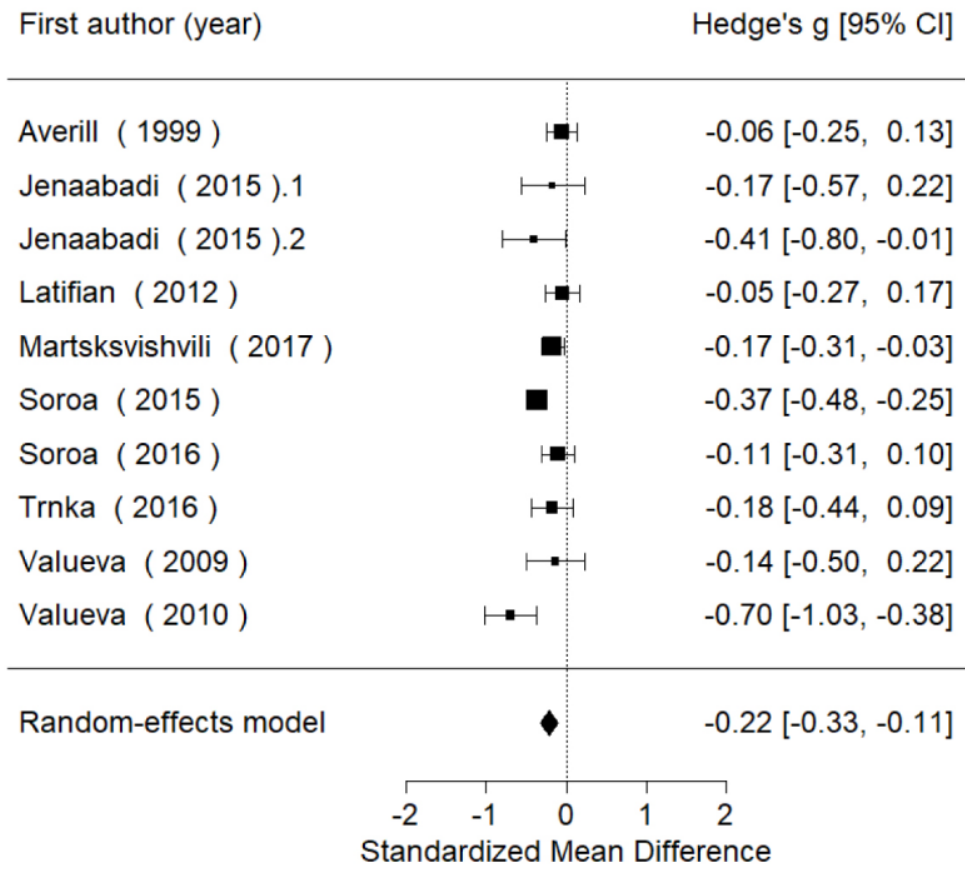

D.Effectiveness/Authenticity

First author (year)

Hedge's g $[95 \% \mathrm{Cl}]$

Averill ( 1999 )
Jenaabadi ( 2015 ).1
Jenaabadi ( 2015 ).2
Latifian ( 2012 )
Martsksvishvili ( 2017 )
Soroa ( 2015 )
Soroa ( 2016 )
Trnka ( 2016 )
Valueva ( 2009 )
Valueva ( 2010 )

$-0.24[-0.43,-0.05]$

$-0.42[-0.81,-0.02]$

$0.17[-0.22,0.57]$

$-0.08[-0.30,0.13]$

$-0.33[-0.48,-0.19]$

$-0.44[-0.56,-0.32]$

$-0.43[-0.64,-0.22]$

$-0.37[-0.63,-0.10]$

$-0.23[-0.59,0.13]$

$-0.40[-0.72,-0.09]$

Random-effects model

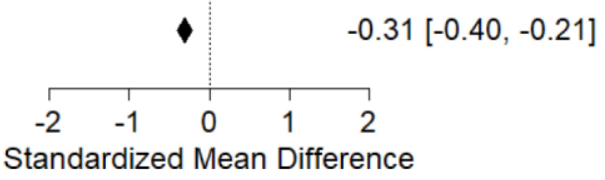


Figure 4. The words mostly co-occurred with emotional creativity (EC) in the corpus

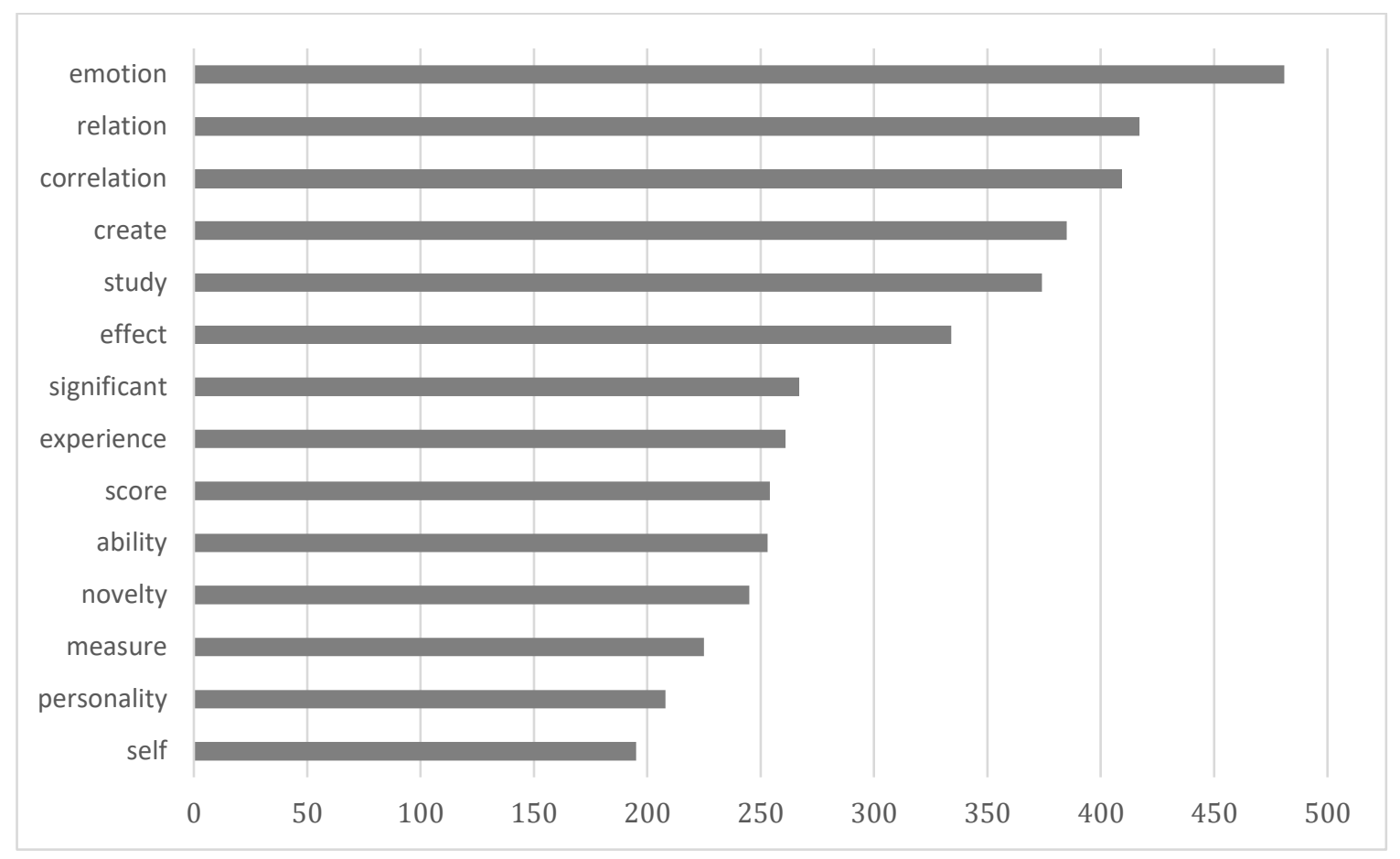


Figure 5. Relationships of the Emotional Creativity Inventory (ECI) total score with other variables

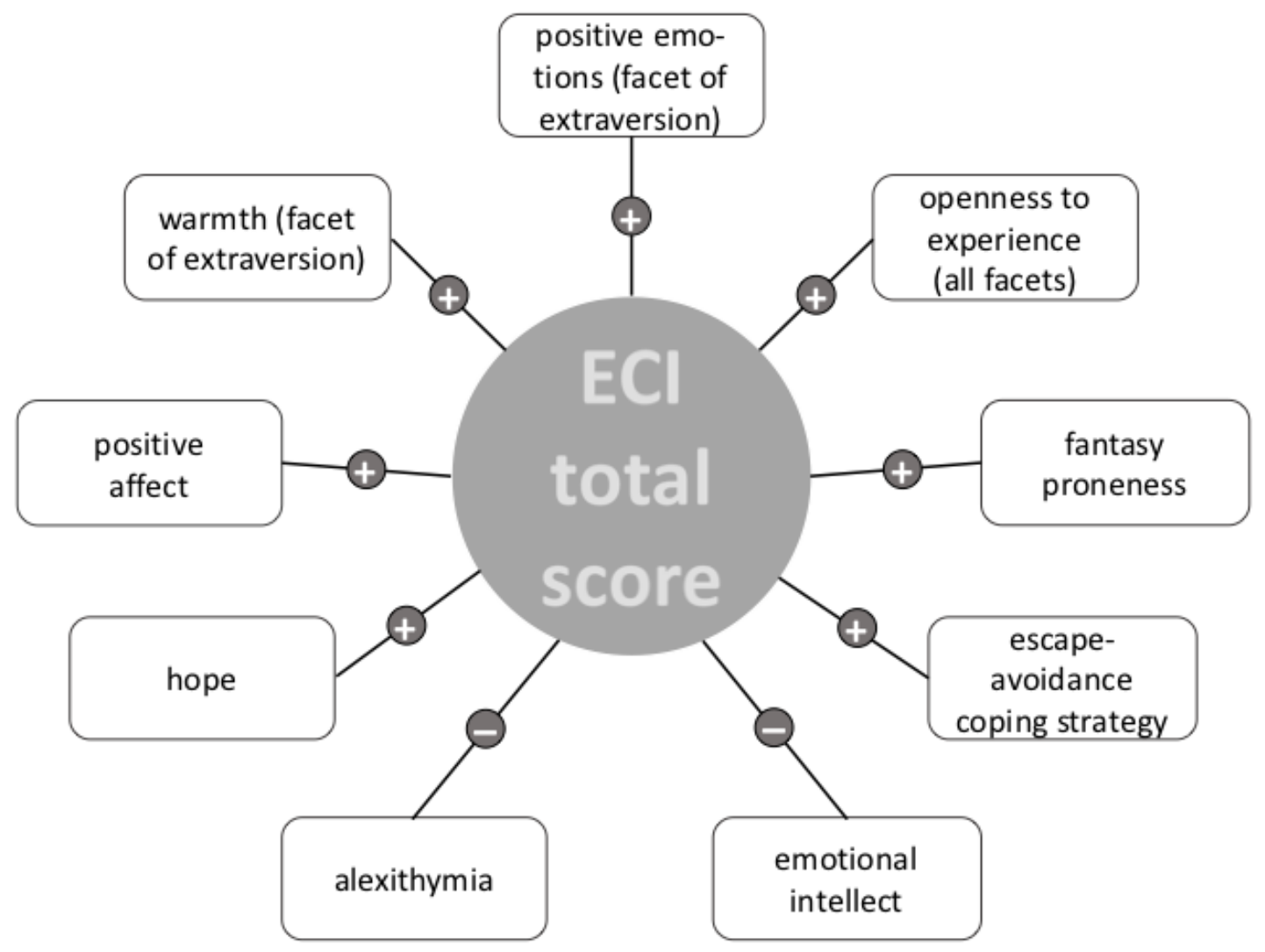


Figure 6. Relationships of the Emotional Creativity Inventory (ECI) subscales with other variables

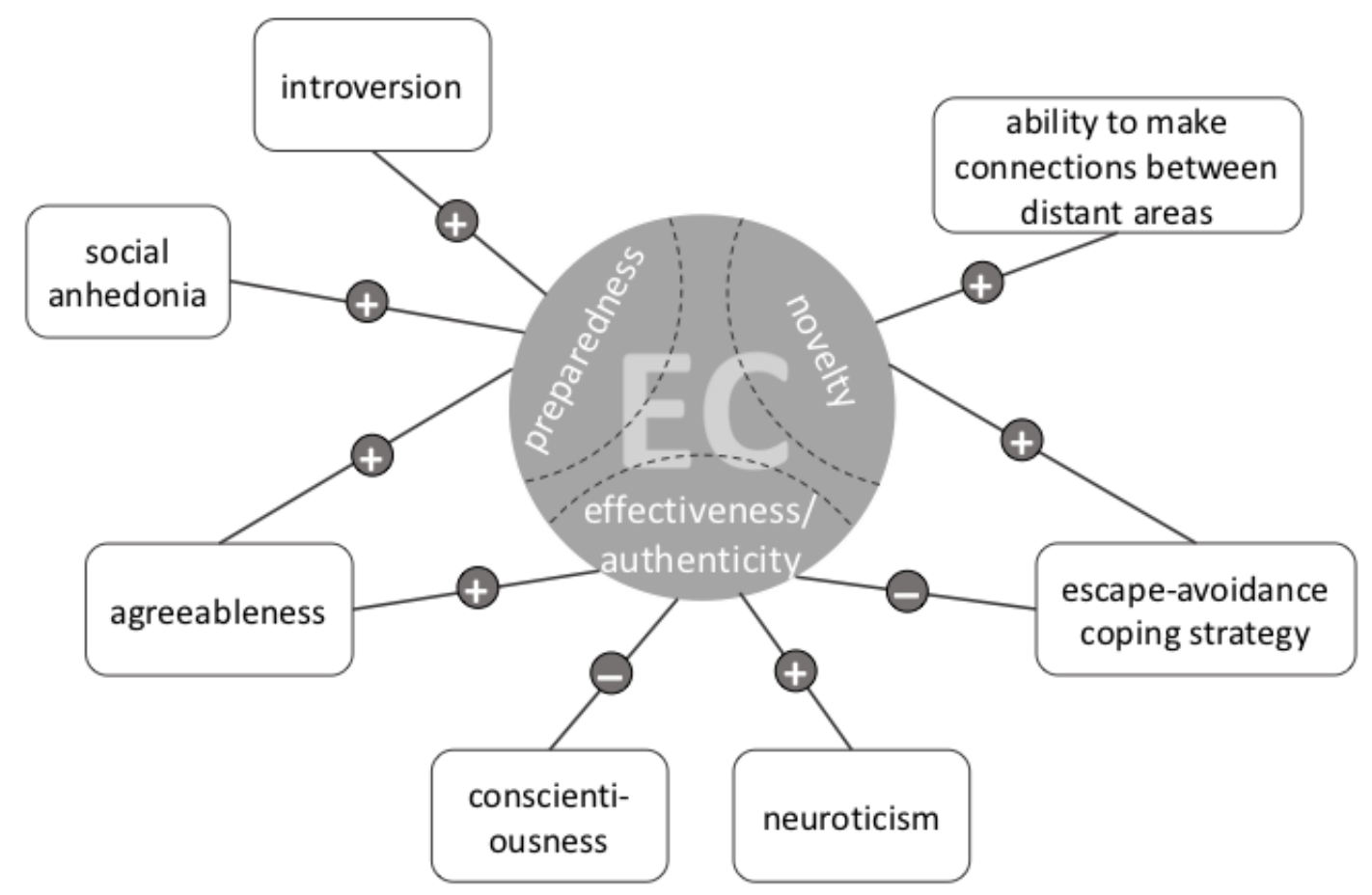


Figure 7. Moderating impacts of emotional creativity (EC) on the abilities, skills and dispositions

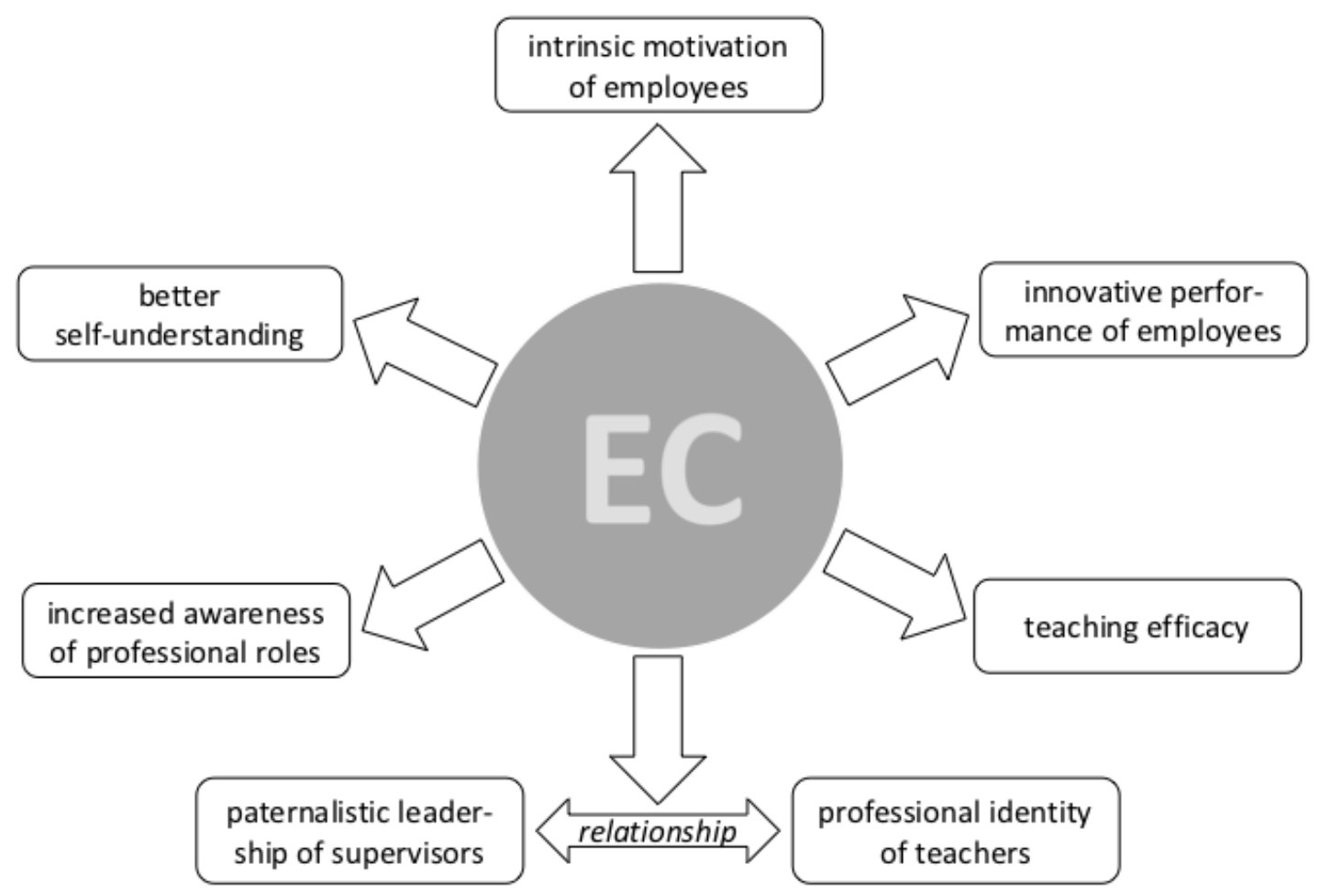


Electronic Supplementary Material 1. The detailed structure of extracted data is as follows: author(s) name(s), year of publication, geographical location of data-mining, participants, sample size(s), emotional creativity (EC) measure (s) involved, and a brief overview of achieved empirical results regarding $E C$

\begin{tabular}{lllll}
\hline $\begin{array}{l}\text { Author/s, year } \\
\text { of publication }\end{array}$ & Country & Population & $\begin{array}{l}\text { Sample } \\
\text { size }\end{array}$ & $\begin{array}{l}\text { EC } \\
\text { measure }\end{array}$ \\
\hline $\begin{array}{l}\text { Abdulaze \& } \\
\text { Martskvishvili } \\
(2016)\end{array}$ & Georgia & $\begin{array}{l}\text { Art and non-art } \\
\text { university } \\
\text { students }\end{array}$ & 80 & ECI \\
\hline $\begin{array}{l}\text { Andreeva } \\
(2011)\end{array}$ & Russia & Students & 48 & ECI \\
\hline Averill (1999) & USA & $\begin{array}{l}\text { Undergraduate } \\
\text { students }\end{array}$ & 489 & ECI
\end{tabular}

\section{Key findings}

Art faculty students had higher ECI scores than students from other faculties. The Novelty subscale of the ECI correlated with a difficulty of describing emotions.

The results showed that the Russian translation of the ECI is valid, reliable, stable, and internally consistent.

Women scored higher than men on the Preparedness and Effectiveness/Authenticity ECI subscales (Study 1). The people who scored high on the ECI were judged by their peers as being emotionally creative (Study 2). The ECI total score correlated with an openness to experience and agreeableness from the Big Five personality inventory (Study 3 ). EC was associated with mystical experiences. Emotionally creative people tended to be confident in their own capabilities (Study 4). Emotionally creative people used a range of coping strategies when faced with a stressful situation. Their emotional lives differed substantially from alexithymics (Study 5). Early trauma and obstacles predisposed a person to be emotionally creative (Study 6).

\begin{tabular}{lllll}
\hline $\begin{array}{l}\text { Derevyanko } \\
(2017)\end{array}$ & Ukraine & $\begin{array}{l}\text { University } \\
\text { students }\end{array}$ & 80 & ECI
\end{tabular}

Emotional awareness and sincerity in the expression of emotions were the most important components for the coping behavior of people with a high level of EC. In the sample of people with a low level of EC, the ability to experience unusual emotions contributed to a positive reassessment and constructive resolution of problems.

\begin{tabular}{|c|c|c|c|c|c|}
\hline $\begin{array}{l}\text { Dyson et al. } \\
(2016)\end{array}$ & $\begin{array}{l}\text { Taiwan, } \\
\text { China }\end{array}$ & $\begin{array}{l}\text { University } \\
\text { students }\end{array}$ & 39 & ECI & $\begin{array}{l}\text { constructive resolution of problems. } \\
\text { The role-playing games were not related to EC. }\end{array}$ \\
\hline Frolova (2016) & Russia & $\begin{array}{l}\text { University } \\
\text { students }\end{array}$ & 30 & ECI & $\begin{array}{l}\text { The ECI was correlated with Frolova's method of measuring } \\
\text { EC. EC training helped to increase EC and coping strategies. }\end{array}$ \\
\hline $\begin{array}{l}\text { Frolova \& } \\
\text { Novoselova } \\
(2015)\end{array}$ & Russia & $\begin{array}{l}\text { Students and } \\
\text { their parents }\end{array}$ & $\begin{array}{l}200 \text { (incl. } \\
50 \text { child / } \\
\text { parent } \\
\text { pairs) }\end{array}$ & $\begin{array}{l}\text { ECI }+ \\
\text { projective/ } \\
\text { associative } \\
\text { tool }\end{array}$ & $\begin{array}{l}\text { EC was positively connected with hardiness and subjective } \\
\text { quality of life. }\end{array}$ \\
\hline $\begin{array}{l}\text { Fuchs et al. } \\
(2007)\end{array}$ & USA & $\begin{array}{l}\text { Students of } \\
\text { psychology }\end{array}$ & 322 & ECI & $\begin{array}{l}\text { ECI and its subscales positively correlated with fantasy } \\
\text { proneness and negatively correlated with the measure of } \\
\text { alexithymia. }\end{array}$ \\
\hline $\begin{array}{l}\text { Ghadiri } \\
\text { Nezhdyan \& } \\
\text { Abdi (2010) }\end{array}$ & Iran & $\begin{array}{l}\text { Undergraduate } \\
\text { students }\end{array}$ & 650 & ECI & $\begin{array}{l}\text { The findings of a confirmatory factor analysis provided support } \\
\text { for the structure of the EC construct in an Iranian community. }\end{array}$ \\
\hline $\begin{array}{l}\text { Golubina } \\
\text { (2013) }\end{array}$ & Russia & $\begin{array}{l}\text { Young and } \\
\text { middle-age } \\
\text { adults }\end{array}$ & 46 & $\begin{array}{l}\text { Berezina } \\
\text { test }\end{array}$ & $\begin{array}{l}\text { A positive correlation between EC (Berezina test) and } \\
\text { emotional intelligence was revealed. }\end{array}$ \\
\hline $\begin{array}{l}\text { Gutbezahl \& } \\
\text { Averill (1996) }\end{array}$ & USA & $\begin{array}{l}\text { Introduction to } \\
\text { Psychology } \\
\text { students }\end{array}$ & $\begin{array}{l}800 \text { (Study } \\
1) ; 900 \\
\text { (Study 2) }\end{array}$ & ECI & $\begin{array}{l}\text { Participants who scored high on the ECI were more } \\
\text { expressionistic; those, who scored low on the ECI were more } \\
\text { pictographic (Study 1). } \\
\text { The ECI correlated with the creativity scores of the narrative } \\
\text { involving a love relationship and with the composite creativity } \\
\text { score for the story (Study 2). }\end{array}$ \\
\hline $\begin{array}{l}\text { Holt et al. } \\
(2008)\end{array}$ & UK & $\begin{array}{l}\text { Psychology } \\
\text { and sociology } \\
\text { students }\end{array}$ & 183 & ECI & $\begin{array}{l}\text { High schizotypes reached higher scores on the ECI than low } \\
\text { schizotypes. }\end{array}$ \\
\hline $\begin{array}{l}\text { Humphreys et } \\
\text { al. (2008) }\end{array}$ & $\begin{array}{l}\text { USA and } \\
\text { China }\end{array}$ & $\begin{array}{l}\text { American and } \\
\text { Chinese MBA } \\
\text { students }\end{array}$ & 70 & ECI & $\begin{array}{l}\text { EC was negatively associated with the desirability of } \\
\text { transformational leadership. The Chinese showed higher scores } \\
\text { on the ECI compared to the Americans. }\end{array}$ \\
\hline
\end{tabular}




\begin{tabular}{|c|c|c|c|c|c|}
\hline $\begin{array}{l}\text { Ivcevic et al. } \\
(2007)\end{array}$ & USA & $\begin{array}{l}\text { Students } \\
\text { (Study 1: age } \\
\text { 17-49; Study 2: } \\
\text { age } 17-19\end{array}$ & $\begin{array}{l}107 \text { (Study } \\
1) ; 113 \\
\text { (Study 2) }\end{array}$ & ECI & $\begin{array}{l}\text { EC and emotional intelligence have been found to be distinct } \\
\text { abilities. EC was mostly uncorrelated with cognitive } \\
\text { intelligence, and it was highly correlated with an openness to } \\
\text { experience from the Big Five personality inventory. }\end{array}$ \\
\hline $\begin{array}{l}\text { Jenaabadi et al. } \\
(2015)\end{array}$ & Iran & $\begin{array}{l}\text { High school } \\
\text { students }\end{array}$ & 200 & ECI & $\begin{array}{l}\text { Gifted students scored higher on the Novelty and } \\
\text { Effectiveness/Authenticity subscales of the ECI than normal } \\
\text { students. }\end{array}$ \\
\hline $\begin{array}{l}\text { Lattifian \& } \\
\text { Delavarpour } \\
(2012)\end{array}$ & Iran & Students & 324 & ECI & $\begin{array}{l}\text { The ECI and its subscales played a mediating role in the } \\
\text { relationship between attachment styles and mental health. }\end{array}$ \\
\hline $\begin{array}{l}\text { Luke \& } \\
\text { Zychowicz } \\
(2014)\end{array}$ & UK & $\begin{array}{l}\text { Psychology } \\
\text { students }\end{array}$ & 40 & ECI & $\begin{array}{l}\text { A medium-sized positive correlation was found between ECI } \\
\text { scores and openness to experience scores. No relationship } \\
\text { between EC and psi scores was found. }\end{array}$ \\
\hline $\begin{array}{l}\text { Martin et al. } \\
(2016)\end{array}$ & $\begin{array}{l}\text { World- } \\
\text { wide }\end{array}$ & $\begin{array}{l}\text { Internet study. } \\
\text { English native } \\
\text { speakers }\end{array}$ & 664 & ECI & $\begin{array}{l}\text { Social anhedonia was positively associated to the Preparedness } \\
\text { ECI subscale. Introversion was negatively associated to the } \\
\text { Preparedness ECI subscale. }\end{array}$ \\
\hline $\begin{array}{l}\text { Martsksvishvili } \\
\text { et al. (2017) }\end{array}$ & Georgia & Students & 834 & ECI & $\begin{array}{l}\text { The psychometric properties of the Georgian version of the ECI } \\
\text { were revealed. }\end{array}$ \\
\hline $\begin{array}{l}\text { Moltafet et al. } \\
(2018)\end{array}$ & Iran & $\begin{array}{l}\text { Undergraduate } \\
\text { students }\end{array}$ & 375 & ECI & $\begin{array}{l}\text { The components of parenting style were shown to predict } \\
\text { students' EC. The styles of parenting using warmth and } \\
\text { structure positively predict the EC of students, and the styles of } \\
\text { parenting using coercion and chaos negatively predict it. The } \\
\text { dimensions of autonomy and the competence of satisfying basic } \\
\text { psychological needs had a mediating role between parenting } \\
\text { style and EC. }\end{array}$ \\
\hline $\begin{array}{l}\text { Navaei et al. } \\
(2014)\end{array}$ & Iran & Women & 240 & ECI & $\begin{array}{l}\text { The ECI subscales showed a difference between married and } \\
\text { divorced women. }\end{array}$ \\
\hline $\begin{array}{l}\text { Oriol et al. } \\
(2016)\end{array}$ & Chile & Students & 428 & ECI & $\begin{array}{l}\text { Developing high levels of dispositional EC enhanced the } \\
\text { activation of positive emotions in the classroom. EC predicted } \\
\text { the intrinsic motivation and academic engagement of university } \\
\text { students. }\end{array}$ \\
\hline $\begin{array}{l}\text { Roe et al. } \\
(2014)\end{array}$ & UK & Students & 34 & ECI & $\begin{array}{l}\text { The ECI was used as one of methods of differentiating } \\
\text { participants into three groups. }\end{array}$ \\
\hline $\begin{array}{l}\text { Sharma \& } \\
\text { Mathur (2016) }\end{array}$ & India & $\begin{array}{l}\text { Undergraduate } \\
\text { students }\end{array}$ & 300 & ECI & $\begin{array}{l}\text { EC was positively correlated with hope and positive affect. } \\
\text { Positive affect mediated the pathway between hope and EC. }\end{array}$ \\
\hline $\begin{array}{l}\text { Singh \& } \\
\text { Kumar (2010) }\end{array}$ & India & $\begin{array}{l}\text { Trainee } \\
\text { teachers }\end{array}$ & 180 & ECI & $\begin{array}{l}\text { On two subscales of the ECI, i.e., Preparedness and } \\
\text { Effectiveness/Authenticity, trainee teachers of in-service } \\
\text { courses scored higher in comparison to teachers of pre-service } \\
\text { courses. }\end{array}$ \\
\hline Song (2016) & China & $\begin{array}{l}\text { Teachers of } \\
\text { English }\end{array}$ & 674 & ECI & $\begin{array}{l}\text { Teachers' EC positively moderated the relationship between } \\
\text { supervisors' paternalistic leadership and teachers' teaching } \\
\text { efficacy. }\end{array}$ \\
\hline $\begin{array}{l}\text { Soroa et al. } \\
(2015)\end{array}$ & Spain & Students & 1145 & $\begin{array}{l}\text { ECI-S } \\
\text { (shortened } \\
\text { Spanish } \\
\text { version of } \\
\text { the ECI) }\end{array}$ & $\begin{array}{l}\text { The paper developed and validated a shortened Spanish version } \\
\text { of the ECI (the ECI-S). High scores on neuroticism were } \\
\text { related to the perception of emotional responses as being novel, } \\
\text { but not effective, whereas people who scored high on } \\
\text { extraversion perceived emotional reactions as effective, but not } \\
\text { novel. The total ECI-S score of women was higher than of men. }\end{array}$ \\
\hline $\begin{array}{l}\text { Soroa et al. } \\
(2016)\end{array}$ & Spain & Students & 594 & $\begin{array}{l}\text { ECI } \\
\text { (shortened } \\
\text { Basque } \\
\text { version) }\end{array}$ & $\begin{array}{l}\text { This paper introduced the adaptation and validation of the ECI } \\
\text { for the Basque-speaking population. Women scored higher than } \\
\text { men on the preparedness and effectiveness/authenticity } \\
\text { subscales. No differences were observed between women and } \\
\text { men on the novelty subscale. }\end{array}$ \\
\hline $\begin{array}{l}\text { Sundararajan } \\
\& \text { Fatemi } \\
(2016)\end{array}$ & Iran & $\begin{array}{l}\text { University } \\
\text { students and } \\
\text { staff }\end{array}$ & 99 & ECI & EC was not found to be a function of relational cognition. \\
\hline $\begin{array}{l}\text { Trnka et al. } \\
(2016)\end{array}$ & $\begin{array}{l}\text { Czech } \\
\text { Republic }\end{array}$ & $\begin{array}{l}\text { University } \\
\text { students, } \\
\text { graduates, and } \\
\text { young adults }\end{array}$ & 251 & ECI & $\begin{array}{l}\text { Art students and graduates scored significantly higher on the } \\
\text { ECI than other majors. The humanities scored significantly } \\
\text { higher than technical/economic majors. Five creative leisure } \\
\text { activities were significantly correlated with the ECI, namely } \\
\text { writing, painting, composing music, performing dramas, and } \\
\text { DIY home improvement. }\end{array}$ \\
\hline $\begin{array}{l}\text { Valueva et al. } \\
(2009)\end{array}$ & Russia & $\begin{array}{l}\text { Psychology } \\
\text { students }\end{array}$ & 179 & ECI & The paper adapted the ECI in the Russian language sample. \\
\hline
\end{tabular}




\begin{tabular}{|c|c|c|c|c|c|}
\hline $\begin{array}{l}\text { Valueva \& } \\
\text { Ushakov } \\
(2010)\end{array}$ & Russia & $\begin{array}{l}\text { High school } \\
\text { students }\end{array}$ & 162 & ECI & $\begin{array}{l}\text { EC was positively correlated to object creativity and negatively } \\
\text { to emotional intellect. }\end{array}$ \\
\hline $\begin{array}{l}\text { Wang et al. } \\
(2015)\end{array}$ & China & $\begin{array}{l}546 \text { supervisor } \\
\text {-subordinate } \\
\text { dyads } \\
\text { Employed at } 18 \\
\text { enterprises } \\
\end{array}$ & 1092 & ECI & $\begin{array}{l}\text { Employees' EC had significant effects on their innovative } \\
\text { performance. The supervisors' support for creativity acted as a } \\
\text { moderator of the relationship between employees' EC and } \\
\text { innovative performance. }\end{array}$ \\
\hline $\begin{array}{l}\text { Zarenezhad et } \\
\text { al. (2013) }\end{array}$ & Iran & $\begin{array}{l}\text { High school } \\
\text { students }\end{array}$ & 400 & ECI & $\begin{array}{l}\text { EC was a positive and significant predictor of educational } \\
\text { adjustment. }\end{array}$ \\
\hline $\begin{array}{l}\text { Zenasni \& } \\
\text { Lubart (2008) }\end{array}$ & France & $\begin{array}{l}\text { Undergraduate } \\
\text { students }\end{array}$ & 107 & ECI & $\begin{array}{l}\text { The ECI was used to evaluate emotional idiosyncrasy. } \\
\text { Individuals tend to experience emotions differently than how } \\
\text { they are reported by the majority of the population. }\end{array}$ \\
\hline
\end{tabular}




\section{Electronic Supplementary Material 2. Breadth of influence}

\begin{tabular}{|c|c|c|c|}
\hline Journal Type / Discipline & $\begin{array}{l}\text { All } \\
\text { Citations }\end{array}$ & $\begin{array}{l}\text { Primary } \\
\text { Citations }\end{array}$ & Journals in Primary Citations Sample \\
\hline Personality Psychology & 8 & 3 & $\begin{array}{l}\text { Journal of Personality; Personality and Individual Differences; Journal of Personality } \\
\text { Disorders }\end{array}$ \\
\hline Social Psychology & 8 & 3 & Social Behavior and Personality; Elsevier Procedia - Social and Behavioral Sciences \\
\hline $\begin{array}{l}\text { Creativity / Cognitive } \\
\text { Psychology }\end{array}$ & 10 & 5 & Creativity Research Journal; Thinking Skills and Creativity \\
\hline Psychology - Multidisciplinary & 10 & 5 & $\begin{array}{l}\text { Spanish Journal of Psychology; Journal of Modern Foreign Psychology; International } \\
\text { Journal of Indian Psychology; Pszichológia; Developmental Psychology: Journal of Iranian } \\
\text { Psychologists }\end{array}$ \\
\hline Cyberpsychology & 2 & 0 & \\
\hline Educational Psychology & 4 & 2 & Frontiers in Psychology - Educational Psychology; Journal on Educational Psychology \\
\hline Organizational Psychology & 7 & 3 & $\begin{array}{l}\text { International Journal of Leadership Studies; Korean Journal of Health Service Management; } \\
\text { Journal of Work and Organizational Psychology }\end{array}$ \\
\hline Theoretical Psychology & 6 & 2 & Psychological Inquiry; Problems of Psychology in the 21 st Century \\
\hline Psychology - Other & 6 & 2 & $\begin{array}{l}\text { Journal of Parapsychology; International Annual Edition of Applied Psychology: Theory, } \\
\text { Research, and Practice }\end{array}$ \\
\hline Other Non-Psychological & 25 & 7 & $\begin{array}{l}\text { Advances in Applied Sociology; Bulletin of Environment, Pharmacology and Life Sciences; } \\
\text { Korean Journal of Health Service Management; Journal of Urmia University of Medical } \\
\text { Sciences; Journal of Urmia Nursing and Midwifery Faculty; Research in Medical } \\
\text { Education; Journal of Life Science and Biomedicine }\end{array}$ \\
\hline Total Citations & 86 & 32 & \\
\hline
\end{tabular}


Electronic Supplementary Material 3. Funnel plots for analyses of gender differences in ECI
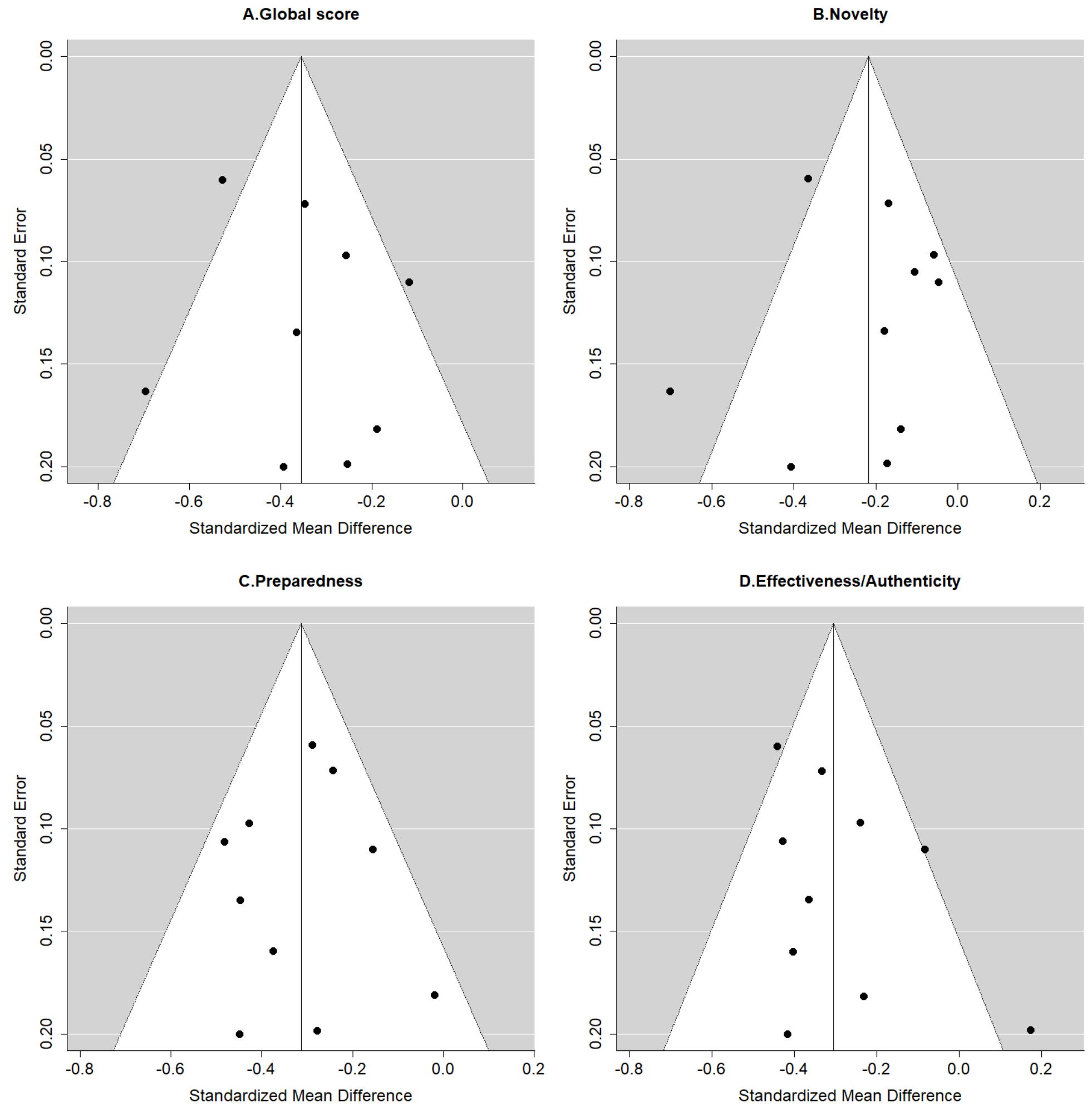